\title{
A Study on the Association of the Chromosome 12 p13 Locus with Sporadic Late-Onset Alzheimer's Disease in Chinese
}

\author{
Yan $\mathrm{Li}^{\mathrm{a}}$ Leung Wing Chu ${ }^{\mathrm{b}, \mathrm{d}, \mathrm{e}}$ Zhong Lif ${ }^{\mathrm{f}}$ Ping-Yiu Yik ${ }^{\mathrm{b}}$ You-Qiang Song ${ }^{\mathrm{a}, \mathrm{c}, \mathrm{e}}$ \\ Departments of ${ }^{\mathrm{a} B i o c h e m i s t r y}$ and ${ }^{\mathrm{b}}$ Medicine, ${ }^{\mathrm{c} C e n t r e}$ for Reproduction, Development and Growth, and \\ ${ }^{d}$ Research Centre of Heart, Brain, Hormone and Healthy Aging, Li Ka Shing Faculty of Medicine, e Alzheimer's \\ Disease Research Network, University of Hong Kong, Hong Kong, SAR, and ${ }^{\mathrm{f}}$ Neurology Department, First Affiliated \\ Hospital of Sun Yat-sen University, Guangzhou, China
}

(C) S. Karger AG, Basel

\section{PROOF Copy for personal use only}

ANY DISTRIBUTION OF THIS ARTICLE WITHOUT WRITTEN CONSENT FROM S. KARGER AG, BASEL IS A VIOLATION OF THE COPYRIGHT.

\section{Key Words}

Alzheimer's disease $\cdot$ Genetics $\cdot$ Chromosome $12 \cdot$

Case-control study

\section{Abstract}

Recent linkage and association studies have implicated the chromosome 12p13 locus as possibly harboring genetic variants predisposed to Alzheimer's disease (AD). We attempted to replicate this association in a Chinese data set comprised of 256 AD cases and 264 age-matched normal controls. A total of 14 single nucleotide polymorphisms (SNPs) were examined. Single marker association revealed the two SNPs in NCAPD2 (rs7311174 and rs2072374) as showing nominal significant $p$ values ( $p=0.0491$ and 0.0116 , respectively). Haplotype analysis found LD block one to be significantly associated with AD (global $p=0.0250$ ). Haplotypes CGGATG and CAGTCG were also significantly associated with AD ( $p=$ 0.0498 and $p=0.0482$, respectively). These genetic analyses provide evidence that the chromosome 12p13 locus is associated with AD in Chinese.

Copyright $\odot 2009$ S. Karger AG, Basel

Y. Li and L.W. Chu contributed equally to the study.
() 2009 S. Karger AG, Basel

$1420-8008 / 09 / 0000-0000 \$ 26.00 / 0$

Fax +4161306 1234 E-Mail karger@karger.ch www.karger.com
Accessible online at: www.karger.com/dem

\section{Introduction}

The pathophysiological process of Alzheimer's disease (AD) is multifactorial but has a genetically heterogeneous background as well. This is evidenced by the widely confirmed genetic risk genes APP, PSEN1, PSEN2, and APOE. However, genomewide linkage studies had located multiple genomic regions that might harbor potentially susceptible genes. Among these candidate regions, the chromosome 12 p13 locus has recently attracted much attention. In fact, the initial genomic screen described linkage of late-onset $\mathrm{AD}$ to the centromeric region markers of chromosome 12 , supported by familial associations [1,2]. Various succeeding replication studies then provided additional evidence linking AD with chromosome 12 [3-5]; in particular, subsequent fine mapping of the chromosome 12 linkage locus and conditional linkage analysis focusing on heterogeneity both found that the linkage to chromosome 12 was independent of the APOE $\varepsilon 4$ allele [6]. Further association analyses have now pointed to a smaller region of the chromosome $12 \mathrm{p} 13$ locus, thus narrowing down late-onset $\mathrm{AD}$ association to single genes as shown by the two recent studies. Of note, a large-scale single nucleotide polymorphisms (SNP)-based association study by Li et al. [7] found strong associations with the GAPD gene, as well as with other genes (CNAP1, PKP2P1) in this re-

You-Qiang Song
Tel. +852 $\mathbf{\square} \mathbf{n}$, Fax +852 $\mathbf{\square} \mathbf{0}$, E-Mail songy@hku.hk 
gion. Consequently in 2008, Lee et al. [8] finely mapped this region, revealing more gene association with late-onset $\mathrm{AD}[7,8]$. In an effort to replicate this finding, we selected the same panel of polymorphism markers and conducted genotyping in our Chinese data set.

\section{Materials and Methods}

The research protocol was approved by the Institutional Review Board (IRB) of the University of Hong Kong and the Hospital Authority Hong Kong West Cluster (HKU/HA HKW IRB). Informed consent was obtained from all individuals participating in this study. A total of 256 Chinese sporadic AD patients and 264 normal subjects were recruited. Demented subjects were recruited consecutively from the Memory Clinic of Queen Mary Hospital of the University of Hong Kong [9-11]. Normal control subjects were recruited from community elderly social centers. All subjects underwent a standardized, semistructured and detailed cognitive assessment protocol for cognitive impairment and dementia. History of memory impairment and cognitive functioning were obtained from both the subjects and informants (either family members or caregivers). Every subject also received a full physical and neurological examination. Standardized cognitive assessment tools including the Chinese versions of Mini-Mental State Examination (MMSE), Alzheimer's Disease Assessment Scale-Cognitive Subscale and Delayed 10-Word Recall Test (DWRT) were administered to all subjects. The DWRT has been reported previously. It consists of 10 Chinese words. Every subject was given three immediate registration and immediate recall trials, which were followed by a delayed free recall trial after $10 \mathrm{~min}$. The number of correct freely recalled words was the DWRT score. Cutoff scores of 26 or above and 6 or above were used for the Chinese MMSE score and DWRT, respectively. All subjects were rated by a single rater (L.W.C.) with the Clinical Dementia Rating Scale (CDR). In the CDR, CDR 0 would mean no cognitive impairment (i.e. normal nondemented persons). For AD patients, the CDR would depend on the stage of the dementia illness and range from CDR 0.5 to 3.0 (i.e. 0.5 very mild, 1.0 mild, 2.0 moderate, 3.0 severe or advanced). All subjects were evaluated by a standardized battery of laboratory investigations including thyroid function tests (serum TSH), serum vitamin $\mathrm{B}_{12}$ and folate levels, and red blood cell folate level. CT brain scans were done for subjects with AD but not for the normal subjects. All normal subjects had CDR ratings of CDR 0 and had no evidence of any neurological disease, while AD subjects were diagnosed in accordance to the NINCDS/ADRDA criteria for probable AD. Subjects with non-AD types of dementia, secondary causes of dementia and familial AD were excluded from the present study [12]. Family history of $\mathrm{AD}$ and dementia in first-degree relatives of subjects (father, mother, brother and/or sister) was reported by family members (spouse, children or sibling) of subjects during the face-to-face interviews. The AD patients' mean age at the time of examination was $79.0 \pm 7.2$ years (ranging from 65 to 97 years), while the controls' mean age was $72.1 \pm 5.6$ years (ranging from 65 to 90 years). As for the disease group, $72.3 \%$ were females and $27.7 \%$ were males, whereas in the control group, $71.7 \%$ were females and $28.3 \%$ were males.

\section{Genetic Analyses}

After obtaining the participants' fully informed consent, blood samples $(10 \mathrm{ml})$ and answers to questionnaires of environmental risk factors were collected. Genomic DNA samples were then isolated from the buffy coat leukocytes, with DNA quality and quantity measured by a DNA fluorometer. Meanwhile, ApoE genotypes were determined by a modified method $[13,14]$.

\section{PCR Amplification/Genotyping}

The Sequenom ${ }^{\circledR}$ platform was used for genotyping, while the Mass ARRAY AssayDesign software (Sequenom) was employed to design amplification and allele-specific extension primers for uniplex or multiplexed assays. The PCR reactions were set up in 384 -well plates at $6 \mathrm{ml}$ total volume per reaction, the reaction mix containing $5 \mathrm{ng}$ genomic DNA, 0.3 pmol each of specific forward and reverse primers, $200 \mathrm{mM}$ each of dNTP, $3.25 \mathrm{mM} \mathrm{MgCl}_{2}$, and 0.2 unit of HotStarTaq polymerase (5 U/ml, Qiagen, Valencia, Calif., USA). The PCR condition was controlled at $95^{\circ} \mathrm{C}$ for $15 \mathrm{~min}$, with 45 cycles of $95^{\circ} \mathrm{C}$ for $20 \mathrm{~s}, 56^{\circ} \mathrm{C}$ for $30 \mathrm{~s}$ and $72^{\circ} \mathrm{C}$ for $1 \mathrm{~min}$, followed by $72^{\circ} \mathrm{C}$ for $3 \mathrm{~min}$. Next, the extension primer was designed to hybridize to the amplicon near the SNP site for the extension of a single or a few bases depending on the allele's genotype. The PCR reactions and PCR product treatment with alkaline phosphatase and mass extend reactions were all performed according to the manufacturer's (Sequenom) protocol. The final base-extension products were later desalted using SpectroClean resin (Sequenom), mixed with 3-hydroxypicolinic acid and analyzed by means of a modified Brucker Autoflex MALDI-TOF mass spectrometer (Brucker, Billerica, Mass., USA).

\section{Statistical Analysis}

Statistical differences in allele and genotype frequencies between the case and control groups were calculated using the $\chi^{2}$ test or Fisher's exact test. Meanwhile, the Hardy-Weinberg equilibrium (HWE) in both groups was performed by the Haploview package v4.0 [15]. Afterwards, the linkage disequilibrium (LD) blocks were estimated using the Gevalt software V2.0 [16]. The LD blocks were defined by Gerbil, an algorithm developed for simultaneous phasing of genotypes into haplotypes as well as block partitioning $[17,18]$. As for all the analyzed polymorphisms, individuals with more than 50\% missing genotypes were excluded. Finally, the haplotype case/control ratios were predicted through the Haploview software v3.2 [15]. Since there was a priori evidence to support candidacy of each of the SNPs studied, and not all markers within genes were independent (i.e. they were in linkage disequilibrium), we did not apply a multiple testing correction.

\section{Results}

The 14 SNPs tested by Lee et al. [8] were examined in our Chinese data set comprised of $256 \mathrm{AD}$ participants and 264 age-matched subjects. All SNPs followed the HWE in both the AD and control groups, except 1 SNP (rs2532500, HWE $\mathrm{p}<0.001$ ) which was found to be significantly associated with $\mathrm{AD}$ as described by Lee et al. [8]. Conversely, the SNPs rs740852 and rs3741924 exhib- 
Table 1. Information of genotyped SNPs in a Chinese data set

\begin{tabular}{|c|c|c|c|c|c|c|c|c|c|c|c|c|c|c|}
\hline \multirow{2}{*}{$\begin{array}{l}\text { Mar- } \\
\text { ker } \\
\text { No. }\end{array}$} & \multirow{2}{*}{$\begin{array}{l}\text { dbSNP rs } \\
\text { No. }\end{array}$} & \multirow{2}{*}{$\begin{array}{l}\text { Physical } \\
\text { position }\end{array}$} & \multirow{2}{*}{$\begin{array}{l}\text { Dist. from } \\
\text { previous } \\
\text { marker, bp }\end{array}$} & \multirow{2}{*}{$\begin{array}{l}\text { Gene } \\
\text { name }\end{array}$} & \multirow[t]{2}{*}{ SNP type } & \multirow[t]{2}{*}{ Alleles } & \multirow{2}{*}{$\begin{array}{l}\text { Risk } \\
\text { allele }\end{array}$} & \multicolumn{2}{|c|}{ Minor allele freq. } & \multicolumn{2}{|c|}{ HWE, $p$ value } & \multicolumn{3}{|c|}{ Single marker, $\mathrm{p}$ value } \\
\hline & & & & & & & & cases & controls & cases & controls & global & $\begin{array}{l}\text { APOE } \\
4+v e\end{array}$ & $\begin{array}{l}\text { APOE } \\
4-v e\end{array}$ \\
\hline 1 & rs2532501 & 6433014 & - & TAPBPL & $\mathrm{NSC}(\mathrm{M} / \mathrm{V})$ & $\mathrm{C} / \mathrm{T}$ & $\mathrm{T}$ & 0.244 & 0.205 & 0.401 & 0.788 & 0.3378 & 0.2547 & 0.1343 \\
\hline 2 & rs 2532500 & 6433071 & 57 & TAPBPL & NSC(T/A) & $\mathrm{C} / \mathrm{T}$ & - & 0.318 & 0.288 & $\begin{array}{l}4.659 \\
\mathrm{E}-10\end{array}$ & $\begin{array}{l}3.674 \\
\text { E-8 }\end{array}$ & - & - & - \\
\hline 3 & rs2008134 & 6458706 & 25,635 & $P K P 2 P 1$ & Intergenic & $\mathrm{A} / \mathrm{G}$ & A & 0.292 & 0.375 & 0.114 & 0.138 & 0.0676 & 0.56 & 0.0304 \\
\hline 4 & rs2072373 & 6502149 & 43,443 & NCAPD2 & IN & G/A & G & 0.361 & 0.388 & 0.285 & 0.077 & 0.5674 & 0.6396 & 0.9913 \\
\hline 5 & rs7311174 & 6505828 & 3,679 & NCAPD2 & IN & $\mathrm{T} / \mathrm{A}$ & $\mathrm{T}$ & 0.258 & 0.345 & 0.104 & 0.309 & 0.0491 & 0.515 & 0.0215 \\
\hline 6 & rs2072374 & 6508106 & 2,278 & NCAPD2 & SC(R) & $\mathrm{C} / \mathrm{T}$ & $\mathrm{C}$ & 0.267 & 0.380 & 0.179 & 0.729 & 0.0116 & 0.7417 & 0.0075 \\
\hline 7 & rs740850 & 6508377 & 271 & NCAPD2 & $\mathrm{SC}(\mathrm{N})$ & G/A & A & 0.243 & 0.210 & 0.163 & 0.889 & 0.4091 & 0.1885 & 0.1736 \\
\hline 8 & rs3741916 & 6514252 & 5,875 & GAPDH & $5^{\prime}$ UTR & $\mathrm{C} / \mathrm{G}$ & C & 0.243 & 0.262 & 0.142 & 0.477 & 0.6773 & 0.334 & 0.7845 \\
\hline 9 & rs3741918 & 6514517 & 265 & GAPDH & IN & $\mathrm{T} / \mathrm{A}$ & A & 0.406 & 0.397 & 0.096 & 1.000 & 0.8488 & 0.8073 & 0.5814 \\
\hline 10 & rs1060620 & 6514983 & 466 & GAPDH & IN & $\mathrm{C} / \mathrm{T}$ & $\mathrm{C}$ & 0.461 & 0.495 & 0.355 & 0.5 & 0.3597 & 0.6386 & 0.3952 \\
\hline 11 & rs1060619 & 6515042 & 59 & GAPDH & IN & G/A & G & 0.457 & 0.490 & 0.238 & 0.648 & 0.2735 & 0.5646 & 0.2831 \\
\hline 12 & rs740852 & 6520587 & 5,545 & $\begin{array}{l}\text { HOM- } \\
\text { TES-103 }\end{array}$ & IN & $\mathrm{C} / \mathrm{C}$ & - & 0.0 & 0.0 & 1.0 & 1.0 & - & - & - \\
\hline 13 & rs1639122 & 6581408 & 60,821 & CHD4 & $\mathrm{NSC}(\mathrm{E} / \mathrm{D})$ & $\mathrm{A} / \mathrm{C}$ & A & 0.466 & 0.485 & 1.0 & 0.734 & 0.3089 & 0.4324 & 0.5856 \\
\hline 14 & rs3741924 & 6600217 & 18,809 & GPR92 & $\mathrm{SC}(\mathrm{A})$ & $\mathrm{G} / \mathrm{G}$ & - & 0.0 & 0.0 & 1.0 & 1.0 & - & - & - \\
\hline
\end{tabular}

NSC = Nonsynonymous coding; $\mathrm{SC}=$ synonymous coding; $\mathrm{IN}=$ intronic.

ited monomorphism in this Chinese data set. Therefore, the three SNPs were excluded from subsequent statistical analysis.

On the other hand, single SNP association analysis found two SNPs, rs7311174 (SNP5) and rs2072374 (SNP6), as showing nominally significant $\mathrm{p}$ values $(\mathrm{p}=0.0491$ and 0.0116 , respectively, table 1). Of note, the T allele of SNP rs7311174 and the C allele of SNP rs2072374 were risk alleles (i.e., their presence predisposes to disease development).

Haplotype analysis was also performed in the 11 SNPs; this revealed two LD blocks spanning this region. On the one hand, LD block one was found to be significantly associated with $A D$, with a global $p$ value of 0.0250 . On the other hand, LD block two did not show any statistical significance. Moreover in LD block one (SNP1-7), haplotypes CGGATG and CAGTCG demonstrated significantly different frequency distributions in the $\mathrm{AD}$ and control groups. Haplotype CAGTCG showed significant uncorrected $\mathrm{p}=0.0482$, while haplotype CGGATG had uncorrected $\mathrm{p}=0.0498$. As a result, both single marker association and haplotype analysis provided evidence that the chromosome $12 \mathrm{p} 13$ locus was associated with AD.

In line with our previous reports on CYP46A1 and ABCA1 using the same Chinese sample pool [14, 19], the classification of samples into $A p o E \varepsilon 4$ allele carrier and non- $\varepsilon 4$ allele carrier groups demonstrated a highly sig-

Association of 12p13 Locus with Sporadic

Late-Onset AD in Chinese nificant difference in terms of allele frequency distributions in both the $\mathrm{AD}$ and control groups $(\mathrm{OR}=3.86,95 \% \mathrm{CI}$ $2.53-5.88, \mathrm{p}<0.0000001)$. Given that several independent groups have reported controversial significance after $A p o E$ $\varepsilon 4$ allele status stratification [6-8], we further analyzed the association in $A p o E \varepsilon 4$-positive and -negative groups. We then determined that SNPs rs7311174 and rs2072374 continued to be significant ( $\mathrm{p}=0.0215$ and 0.0075$)$ in the absence of the ApoE $\varepsilon 4$ allele, while anotherSNP, rs2008134, also exhibited significant association $(\mathrm{p}=0.0304)$. However, no significance could be found for the ApoE $\varepsilon 4$-positive group (table 1). Detailed information of sample stratification by $A p o E \varepsilon 4$ allele is listed in online supplemen-

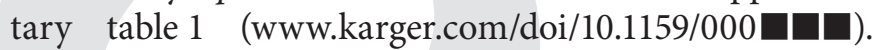
Meanwhile, haplotype analysis in the ApoE $\varepsilon 4$-negative group only confirmed haplotype CGGATG association with an uncorrected $\mathrm{p}$ value of 0.0230 (table 2).

\section{Discussion}

The chromosome $12 \mathrm{p} 13$ region was associated with late-onset and sporadic AD as evidenced in this Chinese data set and as described by Lee et al. [8]. In their Caucasian data set, Lee et al. [8] found a strong significance of single marker association (SNPs rs2532500 and rs740850). Correspondingly, the Chinese data set's SNPs rs7311174 and rs2072374 in this region were found to have an asso- 
Table 2. Haplotype distributions in LD block one

\begin{tabular}{|c|c|c|c|c|}
\hline \multirow[t]{2}{*}{ Haplotype } & \multirow{2}{*}{$\begin{array}{l}\text { Case, } \\
\text { CTL freq. }\end{array}$} & \multirow[t]{2}{*}{$\mathrm{p}$ value } & \multicolumn{2}{|c|}{$A P O E$ 4-negative } \\
\hline & & & case, CTL freq. & $\mathrm{p}$ value \\
\hline CAATCG & $0.319,0.303$ & 0.7938 & $0.343,0.304$ & 0.4991 \\
\hline CGGATG & $0.255,0.326$ & 0.0497 & $0.246,0.348$ & 0.0230 \\
\hline TAGTCA & $0.235,0.202$ & 0.1774 & $0.247,0.181$ & 0.0663 \\
\hline CAGTCG & $0.134,0.078$ & 0.0482 & $0.102,0.070$ & 0.3398 \\
\hline Global p value & \multicolumn{2}{|c|}{0.025} & \multicolumn{2}{|c|}{0.084} \\
\hline
\end{tabular}

$\mathrm{CTL}=$ Control; freq. $=$ frequency.

ciation. These two significant SNPs also contributed to the haplotype association, while allele frequencies in controls of the two significant SNPs were similar to those in the Hapmap HCB data set.

The LD block prediction and haplotype analysis provided further evidence that the Chr12p13 region harbored a risk locus for AD. Apparently, the LD block construction was different between the Caucasian and Chinese populations. In the Chinese population, two large LD blocks across the chromosome 12p13 locus were defined in this report. Conversely, Lee et al. [8] predicted three comparatively smaller LD blocks: SNPs1-2 in LD block one, SNPs5-6 (or 5-7) in block two, and SNPs10-11 in block three.

The comparatively longer LD block one in the Chinese data set encompassed the first two significant blocks shown in the study by Lee et al. [8]. This long LD block also included the SNP rs2532500, which did not follow the HWE in our Chinese data set, although it was found significant in Lee et al. [8]. Subsequent haplotype association likewise found the two haplotypes, CGGATG and CAGTCG, to be associated with AD in the Chinese. It was then determined that haplotype CGGATG was a protective haplotype, while haplotype CAGTCG was its riskconferring counterpart.

Linkage and linkage disequilibrium studies have pointed to several candidate genes on Chr12. Among them A2M, GAPDH, LRP1, GNB3 and NCAPD2 are the most frequently studied candidate genes. In Lee et al. [8], regions surrounding GAPDH and NCAPD2 comprised significant signals in both allelic and haplotype associations and the NCAPD2 association was replicated in this Chinese study. NCAPD2 is short for non-SMC (structural maintenance of chromosomes) condensin I complex, subunit D2, and is a chromosome condensation-related protein. Previous studies relating chromosome and aging have suggested a link between remodeling of chromatin structure and aging, which provided one aspect of functional evidence for the genetic linkage $[20,21]$.

Worth mentioning in association analyses is that genetic heterogeneity is always a factor leading to ambiguous and controversial results. As in chromosome 12 studies, despite the significant evidence of association shown by initial genome screen [1] and following positive replications $[4,5,22]$, Blacker et al. $[23,24]$ by genome scan had reported equivocal results from prior published casecontrol and familial studies. Their failure to detect a positive association signal might be due to the mixed sample set they used, which was composed of varied family structure. In addition, the SNP rs3741916 in GAPDH were found to be associated with $\mathrm{AD}$ in several Caucasian data sets $[7,8,25]$, although we could not replicate the findings in our Chinese population. This may be due to this SNP's insufficient power in the replication data set, or genetic heterogeneity among different ethnic groups.

Particularly with $\mathrm{AD}$ association, the $A p o E \varepsilon 4$ allele plays a critical role due to its strong effect in the AD neuropathological process, therefore generating conflicting results in these studies. Indeed, several investigations revealed that in $A p o E \varepsilon 4$ allele-positive groups, there is an association of the chromosome 12 locus with late-onset AD $[5,8]$, while other studies described no confounding effect of the ApoE $\varepsilon 4$ allele [6,7]. In this analysis, we could confirm that the chromosome 12 locus associated with $\mathrm{AD}$ is independent of the $A p o E \varepsilon 4$ allele.

\section{Conclusion}

The association of chromosome 12p13 multiple loci with $\mathrm{AD}$ was confirmed in a Chinese data set. Both single marker and haplotypic associations were significant. Nonetheless, future genetic studies to verify this association will need to conduct studies with a larger data set and with other ethnic groups. Additionally, a genomewide association effort to discover other potentially susceptible genetic loci would be of great help to unravel the underlying mechanism of $\mathrm{AD}$ development.

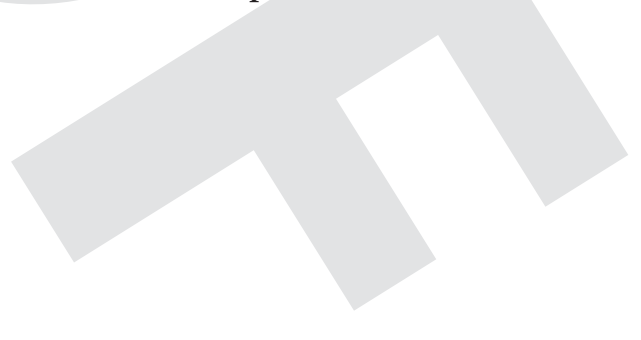




\section{References}

1 Pericak-Vance MA, Bass MP, Yamaoka LH, Gaskell PC, Scott WK, Terwedow HA, Menold MM, Conneally PM, Small GW, Vance JM, Saunders AM, Roses AD, Haines JL: Complete genomic screen in late-onset familial Alzheimer disease: evidence for a new locus on chromosome 12. JAMA 1997;278: 1237-1241.

2 Rimmler JB, Gaskell PC, Aboudonia S, Welsh-Bohmer K, Jackson CE, Schamel M, Yamaoka L, Haines JL, Pericak-Vance MA: A genomic screen in extended Amish families supports a locus on chromosome 12 for $\mathrm{Alz}$ heimer disease (AD). Am J Hum Genet 1997; 61:A292.

3 Scott WK, Grubber JM, Abou-Donia SM, Church TD, Saunders AM, Roses AD, Pericak-Vance MA, Conneally PM, Small GW, Haines JL: Further evidence linking late-onset Alzheimer disease with chromosome 12 . JAMA 1999;281:513-514.

4 Wu WS, Holmans P, Wavrant-DeVrieze F, Shears S, Kehoe P, Crook R, Booth J, Williams N, Perez-Tur J, Roehl K, Fenton I, Chartier-Harlin MC, Lovestone S, Williams J, Hutton M, Hardy J, Owen MJ, Goate A: Genetic studies on chromosome 12 in lateonset Alzheimer disease. JAMA 1998;280 619-622.

5 Rogaeva E, Premkumar S, Song Y, Sorbi S, Brindle N, Paterson A, Duara R, Levesque G, Yu G, Nishimura M, Ikeda M, O’Toole C, Kawarai T, Jorge R, Vilarino D, Bruni AC, Farrer LA, St George-Hyslop PH: Evidence for an Alzheimer disease susceptibility locus on chromosome 12 and for further locus heterogeneity. JAMA 1998;280:614-618.

6 Scott WK, Grubber JM, Conneally PM, Small GW, Hulette CM, Rosenberg CK, Saunders AM, Roses AD, Haines JL, PericakVance MA: Fine mapping of the chromosome 12 late-onset Alzheimer disease locus: potential genetic and phenotypic heterogeneity. Am J Hum Genet 2000;66:922-932.

7 Li Y, Nowotny P, Holmans P, Smemo S, Kauwe JS, Hinrichs AL, Tacey K, Doil L, van Luchene R, Garcia V, Rowland C, Schrodi S, Leong D, Gogic G, Chan J, Cravchik A, Ross D, Lau K, Kwok S, Chang SY, Catanese J, Sninsky J, White TJ, Hardy J, Powell J, Lovestone S, Morris JC, Thal L, Owen M, Williams J, Goate A, Grupe A: Association of late-onset Alzheimer's disease with genetic variation in multiple members of the gapd gene family. [Erratum in Proc Natl Acad Sci USA 2006; 103:6411]. Proc Natl Acad Sci USA 2004;101:15688-15693.
8 Lee JH, Cheng R, Rogaeva E, Meng Y, Stern Y, Santana V, Lantigua R, Medrano M, Jimenez-Velazquez IZ, Farrer LA, St GeorgeHyslop P, Mayeux R: Further examination of the candidate genes in chromosome $12 \mathrm{p} 13$ locus for late-onset Alzheimer disease. Neurogenetics 2008;9:127-138.

9 McKhann G, Drachman D, Folstein M Katzman R, Price D, Stadlan EM: Clinical diagnosis of Alzheimer's disease: report of the NINCDS-ADRDA work group under the auspices of Department of Health and $\mathrm{Hu}$ man Services Task Force on Alzheimer's Disease. Neurology 1984;34:939-944.

10 Chiu KC, Chu LW, Chung CP, Hu W, Chan F, Pei C, Hui SL: Clinical features of Alzheimer's disease in a regional memory clinic in Hong Kong. J Hong Kong Geriatr Soc 2002;11:21-27.

11 Chu LW, Ma ES, Lam KK, Chan MF, Lee DH: Increased alpha 7 nicotinic acetylcholine receptor protein levels in Alzheimer's disease patients. Dement Geriatr Cogn Disord 2005; 19:106-112.

12 Chu LW, Tam S, Lee PWH, Wong RLC, Yik PY, Tsui W, Song Y, Cheung BMY, Morley JE, Lam KSL: Bioavailable testosterone is associated with a reduced risk of amnestic mild cognitive impairment in older men. Clin Endocrinol 2008;68:589-598.

13 Song YQ, Rogaeva E, Premkumar S, Brindle N, Kawarai T, Orlacchio A, Yu G, Levesque G, Nishimura M, Ikeda M, Pei Y, O’Toole C, Duara R, Barker W, Sorbi S, Freedman M, Farrer L, St George-Hyslop P: Absence of association between Alzheimer disease and the -491 regulatory region polymorphism of APOE. Neurosci Lett 1998;250:189-192.

14 Li Y, Chu LW, Chen YQ, Cheung BM, Leung RY, Yik PY, Ng KM, Mak W, Jin DY, St George-Hyslop P, Song YQ: Intron $2(\mathrm{t} / \mathrm{c})$ cyp46 polymorphism is associated with Alzheimer's disease in Chinese patients. Dement Geriatr Cogn Disord 2006;22:399_ 404.

15 Barrett JC, Fry B, Maller J, Daly MJ: Haploview: analysis and visualization of $\mathrm{LD}$ and haplotype maps. Bioinformatics 2005;21: 263-265.
16 Davidovich O, Kimmel G, Shamir R: Gevalt: an integrated software tool for genotype analysis. BMC Bioinformatics 2007;8:36.

17 Kimmel G, Shamir R: Gerbil: genotype resolution and block identification using likelihood. Proc Nat Acad Sci USA 2005;102:158162.

18 Kimmel G, Shamir R: Maximum likelihood resolution of multi-block genotypes. Proc 8th Annu Int Conf on Res in Computational Mol Biol (RECOMB 04), San Diego, 2004, pp $2-9$.

19 Chu LW, Li Y, Li Z, Tang AY, Cheung BM, Leung RY, Yik PY, Jin DY, Song YQ: A novel intronic polymorphism of ABCA1 gene reveals risk for sporadic Alzheimer's disease in Chinese. Am J Med Genet B Neuropsychiatr Genet 2007;144B:1007-1013.

20 Lezhava T: Chromosome and aging: genetic conception of aging. Biogerontology 2001;2: 253-260.

21 Adams PD: Remodeling of chromatin structure in senescent cells and its potential impact on tumor suppression and aging. Gene 2007;397:84-93.

22 Mayeux R, Lee JH, Romas SN, Mayo D, Santana V, Williamson J, Ciappa A, Rondon HZ, Estevez P, Lantigua R, Medrano M, Torres M, Stern Y, Tycko B, Knowles JA: Chromosome-12 mapping of late-onset Alzheimer disease among Caribbean Hispanics. Am J Hum Genet 2002;70:237-243.

23 Blacker D, Wilcox MA, Laird NM, Rodes L, Horvath SM, Go RC, Perry R, Watson B Jr, Bassett SS, McInnis MG, Albert MS, Hyman BT, Tanzi RE: Alpha-2 macroglobulin is genetically associated with Alzheimer disease. Nat Genet 1998;19:357-360.

24 Blacker D BL, Saunders AJ, Moscarillo TJ, Albert MS, Wiener H, Perry RT, Collins JS, Harrell LE, Go RC, Mahoney A, Beaty T, Fallin MD, Avramopoulos D, Chase GA, Folstein MF, McInnis MG, Bassett SS, Doheny KJ, Pugh EW, Tanzi RE; NIMH Genetics Initiative Alzheimer's Disease Study Group: Results of a high-resolution genome screen of 437 Alzheimer's disease families. Hum Mol Genet 2003;12:23-32.

25 Lin PI, Martin ER, Bronson PG, BrowningLarge C, Small GW, Schmechel DE, WelshBohmer KA, Haines JL, Gilbert JR, PericakVance MA: Exploring the association of glyceraldehyde-3-phosphate dehydrogenase gene and Alzheimer disease. Neurology 2006;67:64-68. 